\title{
Disorders of bone-mineral metabolism and their correction with women who have body weight deficiency at pregravid stage and during pregnancy
}

\author{
L. P. Shelestova \\ Donetsk National Medical University, Lyman, Ukraine
}

Key words:

body weight,

preventive

medicine,

preconception

care, pregnancy,

bone-density,

densitometry.

\section{Zaporozhye}

medical journal

2017; 19 (5), 618-622

Dol:

10.14739/2310-1210

2017.5.110167

E-mail:

larysa.shelestova@

gmail.com
The processes in bone-mineral metabolism provide normal course of pregnancy, labour and fetus development, women with body weight deficiency are at risk reduction of bone tissue mineral density, progressing of osteopenia and osteoporosis. This shows the necessity of medical and preventive measures that have the aim to correct calcium- phosphorus and bone metabolism with women who have body weight deficiency.

Aim. To elaborate and to evaluate medical and preventive measures that have the aim to correct disorders in bone-mineral metabolism with women who have body weight deficiency at pregravid stage and during pregnancy.

Materials and methods. The efficiency of adding combined medicine of calcium carbonate and cholecalciferol and dietary nourishment to traditional treatment that affected the state of bone-mineral metabolism with women who have body weight deficiency at pregravid stage and during pregnancy was studied.

Results. With women who have body weight deficiency at pregravid stage and during pregnancy it is noted statistically considerable reduction in blood of total calcium and bone tissue markers that grows with the course of gestation. The changes in mineral density of bone tissue can be seen from the existence of osteopenic syndrome at pregravid stage that occurs with every third woman who has body weight deficiency and with every second before labour. The use of elaborated medical and preventive measures including combined medicine of calcium carbonate and cholecalciferol allows to normalize the indexes of bone-mineral metabolism with women who have body weight deficiency.

Conclusions. Women with body weight deficiency already at pregravid stage have disorders in bone metabolism and coming of pregnancy lead to aggravation of bone metabolism disorders. The additional use of combined medicine of calcium carbonate and cholecalciferol and dietary nourishment made the indexes of calcium-phosphorus and bone metabolism better and osteopenic syndrome less frequent.
Киючові слова:

маса тіка,

профікактична

медицина,

підготовка

Ао вагітності,

вагітність,

кістки щільність,

Аенситометрія.

Запорізький

медичний

журнал. - 2017.

T. 19, № 5(104). -

C. 618-622

\section{Порушення кістково-мінерального обміну та їх корекція в жінок із дефіцитом маси тіка на прегравідарному етапі та під час вагітності}

\section{^. П. Шелестова}

Процеси в кістково-мінеральному обміні забезпечують нормальний перебіг вагітності, пологів і розвиток плода, а жінки 3 дефіцитом маси тіла становлять групу ризику зі зниження мінеральної щільності кісткової тканини, розвитку остеопенії та остеопорозу. Це вказує на необхідність розроблення лікувально-профілактичних заходів, що спрямовані на корекцію кальцій-фосфрорного та кісткового метаболізму в жінок із дефіцитом маси тіла.

Мета роботи - розробка та оцінювання лікувально-профілактичних заходів, що спрямовані на корекцію порушень кістково-мінерального обміну в жінок із дефіцитом маси тіла на прегравідарному етапі та під час вагітності.

Матеріали та методи. Вивчена ефективність додаткового призначення до традиційного лікування комбінованого препарату карбонату кальцію та холекальциферолу й лікувального харчування на стан кістково-мінерального обміну в жінок із десріцитом маси тіла на прегравідарному етапі та під час вагітності.

Результати. У жінок із дефіцитом маси тіла на прегравідарному етапі та під час вагітності відзначається статистично значуще зниження у крові рівнів загального кальцію та маркерів кісткової тканини, що посилюється зі збільшенням терміну гестації. На зміну мінеральної щільності кісткової тканини вказує наявність остеопенічного синдрому на прегравідарному етапі в кожної третьої жінки з дефріцитом маси тіла, а напередодні пологів - у кожної другої. Використання розроблених лікувально-профрілактичних заходів із включенням комбінованого препарату карбонату кальцію та холекальциферолу дає можливість нормалізувати показники кістково-мінерального обміну в жінок із дефіцитом маси тіла.

Висновки. У жінок із дефіцитом маси тіла ще на прегравідарному етапі мають місце порушення кісткового метаболізму, а настання вагітності сприяє посиленню порушень кісткового обміну. На тлі додаткового застосування комбінованого препарату карбонату кальцію та холекальциферолу й лікувального харчування відзначається поліпшення показників кальцій-фросфорного обміну та кісткового метаболізму, зменшення частоти остеопенічного синдрому.
Ключевые слова: масса тела, профилактическая медицина, прегравидарный этап, поАготовка к беременности, беременность, кости п^Отность, Аенситометрия.

\section{Нарушения костно-минерального обмена и их коррекция у женщин с дефицитом массы тела на прегравидарном этапе и во время беременности}

\section{^. П. Шелестова}

Процессы в костно-минеральном обмене обеспечивают нормальное течение беременности, родов и развитие плода, а женщины с дефицитом массы тела входят в группу риска по снижению минеральной плотности костной ткани, развитию остеопении и остеопороза. Это указывает на необходимость разработки лечебно-профилактических мероприятий, направленных на коррекцию кальций-фросфорного и костного метаболизма у женщин с дефицитом массы тела. 
Цель работы - разработка и оценка лечебно-профилактических мероприятий, направленных на коррекцию нарушений костно-минерального обмена у женщин с дефицитом массы тела на прегравидарном этапе и во время беременности.

Материалы и методы. Изучена эффективность дополнительного назначения к традиционному лечению комбинированного препарата карбоната кальция и холекальциферола и лечебного питания на состояние костно-минерального обмена у женщин с дефицитом массы тела на прегравидарном этапе и во время беременности.

Результаты. У женщин с дефицитом массы тела на прегравидарном этапе и во время беременности отмечается статистически значимое снижение в крови уровней общего кальция и маркеров костной ткани, усиливающееся с увеличением срока гестации. На изменение минеральной плотности костной ткани указывает наличие остеопенического синдрома на прегравидарном этапе у каждой третьей женщины с дефицитом массы тела, а накануне родов - у каждой второй. Использование разработанных лечебно-профилактических мероприятий с включением комбинированного препарата карбоната кальция и холекальциферола позволяет нормализовать показатели костно-минерального обмена у женщин с дефицитом массы тела.

Выводы. У женщин с дефицитом массы тела ещё на прегравидарном этапе имеют место нарушения костного метаболизма, а наступление беременности способствует усилению нарушений костного обмена. На фоне дополнительного применения комбинированного препарата карбоната кальция и холекальциферола и лечебного питания отмечается улучшение показателей кальций-фосфорного обмена и костного метаболизма, уменьшение частоты остеопенического синдрома.

Lately the problems of metabolic disorders in bone system with young people are in the center of attention. The density of bone tissue is affected by the state of hormone homeostasis, level of physical activity, nutrition peculiarities (insufficient receiving of calcium and vitamin $D$ by body), genetic factors, as well as pregnancy and lactation $[1,2]$. Nowadays there appear more and more works about the role of vitamin $D$ deficiency in the pathogenesis of not only pathology of bone system, but in pregnancy complications and perinatal consequences as well $[3,4]$. Vitamin $D$ deficiency is considered one of the main problems in Healthcare all over the world and according to World Health Organization it has pandemic character [2]. Among the causes of disorders of bone tissue metabolism with the pregnant, body weight deficiency (BWD) plays a significant role as the result of alimentary factor, in particular, insufficient consumption of protein, calcium, vitamin $D$ with food [5]. It also has been proved that BWD is one of the leading factors of osteopenia and osteoporosis formation [6], and women with low body weight are at risk on reduction of bone tissue mineral density [2]. At the same time the processes in bone-mineral metabolism provide the normal course of pregnancy, labour and fetus development. All the abovesaid indicates the necessity of planning the medical and preventive measures that have the aim to correct calcium-phosphorus and bone metabolism at the stage of pregravid preparation and during pregnancy with women who have BWD.

\section{Aim}

Elaboration and evaluation of medical and preventive measures that have the aim to correct bone-mineral metabolism disorders with women who have body weight deficiency at the pregravid stage and during pregnancy.

\section{Materials and methods}

The research included 130 women with BWD randomized into two groups: group of suggested measures - 65 women at the pregravid stage and 50 of them during pregnancy and before labour and group of traditional measures -65 women at pregravid stage and 41 of who with the coming of pregnancy and 37 before labour. Also a group of 35 women with normal body weight (NBW), pregnant and not pregnant was selected.
Laboratory tests were held four times: at woman's registration for pregnancy planning, repeated examination at pregravid stage (after $6-8$ months), with coming of pregnancy (8-10 weeks of gestation) and before labour (36-38 weeks).

The body weight deficiency was defined according to WHO recommendations on body weight index (1997).

To find out the total calcium in blood serum the following methods were used: the colorimetric method, nonorganic phosphor - spectrophotometric, parathyroid hormone (PTH), osteocalcin and vitamin D $(25(\mathrm{OH}) \mathrm{D})$ total - immunochemical with electrochemiluminescent detection (ECLIA) with usage of test-system Roche Diagnostics (Switzerland) on Cobas analyzer 6000 (with 501 module) of Roche Diagnostics (Switzerland).

The research of bone tissue mineral density was held with the usage of ultrasound densitometric apparatus Omnisense 7000 .

All women got traditional treatment and preventive measures according to valid protocol of Healthcare Ministry of Ukraine.

Women from the suggested measures group additionally received combined medicine of calcium carbonate $1250 \mathrm{mg}$ and cholecalciferol $200 \mathrm{ME}$ per orally: at disorders of calcium-phosphorus and bone metabolism three times per 24 hours during three courses of 6 weeks at pregravid stage with one month interval between courses and during pregnancy at 10-12, 20-22 and 30-32 weeks of gestation; when there were no disorders of calcium-phosphorus and bone metabolism it was prescribed twice per 24 hours at pregravid stage during three courses of 4 weeks, with one month interval between courses and during pregnancy at 10-12, 20-22 and 30-32 weeks of gestation.

Dietary nutrition with women who have BWD should mainly consist of proteins, carbohydrates; food taking is 4-5 times a day. The amount of day ration calories should be distributed as following: proteins $-35 \%$, fats $-20 \%$, carbohydrates - $45 \%$. Diet is corrected considering concomitant pathology of gastrointestinal tract. Keeping register of nutrition will help to control the nutrition.

The processing of statistical information data was held with the usage of software SPSS Statistics17.0. As the majority of variables didn't correspond to normal distribution, they were represented by median (Me) and interquartile latitude -25 and 75 percentile $(25 ; 75 \%)$. The comparison of quantitative data of three independent groups were 
made with the help of Kruskal-Wallis H-test. If differences were revealed then the comparison of groups in pairs were held with the help of Mann-Whitney test with critical level of rate 0.017 (Bonferroni correction for multiple comparisons). The comparison of qualitative signs was made with the usage of $X^{2}$ Pearson Chi-square with Yates's correction.

The parameters of effective treatments are shown in the research. Absolute risk reduction (ARR) - is absolute arithmetic difference in the frequency of adverse outcome between groups. Relative Risk Reduction (RRR) - is relative reduction of frequencies of adverse outcomes. The number of patients needed to treat (NNT) with certain method to prevent unfavourable outcome for one patient. Confidence interval $(\mathrm{Cl})$ shows in what limits true ranges can vary in population.

\section{Results and discussion}

While addressing of women to the women's consultation for pregnancy planning it was noted that the total calcium concentration with women who have BWD was considerably lower than with women who had NBW. Taking calcium carbonate and cholecalciferol at the pregravid stage contributed to normalization of this rate in the group of suggested measures. The rise of total calcium concentration in the group of traditional measures can be explained by hormone replacement therapy, prescribed according to valid protocols of Healthcare Ministry of Ukraine and it influenced favorably the density of bone tissue. Notwithstanding the abovementioned rise, calcium level was statistically considerably lower than in group of suggested measures and NBW. The same tendency was observed and at the beginning of pregnancy. Further researches showed the reduction of total calcium concentration before labour in comparison with the beginning of pregnancy in all groups. But comparison of groups by pairs before labour showed that with women who had BWD and traditional treatment the concentration of total calcium was considerably less than with women who got calcium carbonate and cholecalciferol. The tendency to reduction of total calcium in blood (Table 1) is noted even with the pregnant who have NBW in comparison with women who received suggested treatment. It is necessary to underline the fact that all women receiving the combined medicine of calcium and cholecalciferol noted that symptoms of calcium insufficiency disappeared which wasn't observed among women who received traditional treatment.

There were no statistically considerable differences between groups in concentration of non-organic phosphorus that can be seen from the results of comparison of variables done with the help of Kruskal-Wallis test (Table 1).

The research studying the peculiarities of bone tissue markers, i. e. PTH, osteocalcin and vitamin D showed just the same results with calcium concentration. So, at first laboratory test the concentration of given indexes with women who had BWD was lowered. Prescription of medical and preventive measures, including combined medicine of calcium and cholecalciferol and dietary nutrition, contributed to the fact that with women from the group of proposed measures at pregravid stage the concentration of given indexes corresponded to the group with NBW, while with those receiving traditional treatment they were statistically considerably less as in comparison with NBW group, as well as with group of suggested measures. With coming of pregnancy and before labour the studied indexes grew less, however the tendency remained the same, that is indexes of given rates with women who received suggested measures nearly corresponded to those which the pregnant with NBW had, unlike group of traditional measures where the considered indexes were statistically considerably less (Table 2).

Together with the detailed study of laboratory data the use of ultrasound densitometry was justified. It is

Table 1. Calcium and phosphorus metabolism (Me (25; $75 \%)$

\begin{tabular}{|c|c|c|c|c|c|}
\hline \multirow[t]{2}{*}{ Index } & \multirow[t]{2}{*}{ Test } & \multirow{2}{*}{$\frac{1}{\text { Suggested measures }}$} & \multirow{2}{*}{$\frac{2}{\text { Traditional measures }}$} & \multirow{2}{*}{$\begin{array}{l}3 \\
\text { NBW }\end{array}$} & \multirow[t]{2}{*}{ Group comparison* } \\
\hline & & & & & \\
\hline \multirow[t]{4}{*}{ Calcium, mmol/l } & First, at pregravid stage & $\begin{array}{l}2.27 \\
(2.21 ; 2.35)\end{array}$ & $\begin{array}{l}2.26 \\
(2.21 ; 2.36)\end{array}$ & $\begin{array}{l}2.36 \\
(2.32 ; 2.42)\end{array}$ & $\begin{array}{l}X^{2}{ }_{(2)}=35.086, P<0.001 \\
1-2 U=2075, Z=-0.2, P=0.859 \\
1-3 U=394, Z=-5.4, P<0.001 \\
2-3 U=397, Z=-5.4, P<0.001\end{array}$ \\
\hline & Repeated, at pregravid stage & $\begin{array}{l}2.41 \\
(2.34 ; 2.45)\end{array}$ & $\begin{array}{l}2.28 \\
(2.24 ; 2.37)\end{array}$ & & $\begin{array}{l}X^{2}=38.538, P<0.001 \\
1-2 U=895, Z=-5.7, P<0.001 \\
1-3 U=971, Z=-1.2, P=0.228 \\
2-3 U=512, Z=-4.5, P<0.001\end{array}$ \\
\hline & Beginning of pregnancy & $\begin{array}{l}2.38 \\
(2.30 ; 2.43)\end{array}$ & $\begin{array}{l}2.25 \\
(2.21 ; 2.32)\end{array}$ & $\begin{array}{l}2.34 \\
(2.26 ; 2.41)\end{array}$ & $\begin{array}{l}X_{1(2)}^{2}=28.090, P<0.001 \\
1-2 U=382, Z=-5.1, P<0.001 \\
1-3 U=667, Z=-1.9, P=0.063 \\
{ }^{2-3} U=400, Z=-3.3, P=\mathbf{0 . 0 0 1}\end{array}$ \\
\hline & Before labour & $\begin{array}{l}2.30 \\
(2.25 ; 2.38)\end{array}$ & $\begin{array}{l}2.20 \\
(2.07 ; 2.30)\end{array}$ & $\begin{array}{l}2.27 \\
(2.23 ; 2.35)\end{array}$ & $\begin{array}{l}X_{1(2)}^{2}=22.191, P<0.001 \\
1-2 U^{2}=401, Z=-4.5, P<0.001 \\
1-3 U=656, Z=-2.0, P=0.050 \\
2-3 U=389, Z=-2.9, P=0.003\end{array}$ \\
\hline \multirow{3}{*}{ Phosphorus, $\mathrm{mmol} / \mathrm{l}$} & Repeated, at pregravid stage & $\begin{array}{l}1.20 \\
(1.16 ; 1.27)\end{array}$ & $\begin{array}{l}1.21 \\
(1.16 ; 1.28)\end{array}$ & & $X_{(2)}^{2}=0.401, P=0.818$ \\
\hline & Beginning of pregnancy & $\begin{array}{l}1.19 \\
(1.15 ; 1.26)\end{array}$ & $\begin{array}{l}1.18 \\
(1.12 ; 1.24)\end{array}$ & $\begin{array}{l}1.21 \\
(1.17 ; 1.29)\end{array}$ & $X_{(2)}^{2}=5.080, P=0.079$ \\
\hline & Before labour & $\begin{array}{l}1.19 \\
(1.14 ; 1.23)\end{array}$ & $\begin{array}{l}1.16 \\
(1.08 ; 1.21)\end{array}$ & $\begin{array}{l}1.20 \\
(1.14 ; 1.25)\end{array}$ & $X_{(2)}^{2}=5.416, P=0.067$ \\
\hline
\end{tabular}

\footnotetext{
*: The comparison of three groups (multiple comparisons Kruskal-Wallis test) further comparisons by pairs (test Mann-Whitney)
} 
Table 2. Markers of bone tissue (Me $(25 ; 75 \%)$

\begin{tabular}{|c|c|c|c|c|c|}
\hline \multirow[t]{2}{*}{ Index } & \multirow[t]{2}{*}{ Test } & \multirow{2}{*}{$\frac{1}{\text { Suggested measures }}$} & \multirow{2}{*}{$\begin{array}{l}2 \\
\text { Traditional measures }\end{array}$} & \multirow{2}{*}{$\frac{3}{\text { NBW }}$} & \multirow[t]{2}{*}{ Group comparison* } \\
\hline & & & & & \\
\hline \multirow[t]{4}{*}{$\begin{array}{l}\text { PTH, } \\
\mathrm{pg} / \mathrm{ml}\end{array}$} & First, at pregravid stage & $\begin{array}{l}24.0 \\
(17.1 ; 30.5)\end{array}$ & $\begin{array}{l}26.0 \\
(17.2 ; 32.6)\end{array}$ & $\begin{array}{l}37.2 \\
(33.0 ; 40.2)\end{array}$ & $\begin{array}{l}X_{1-2)}^{2}=43.837, P<0.001 \\
{ }_{1-2}=1932, Z=-0.8, P=0.401 \\
{ }^{2-3} U=335, Z=-6.1, P<0.001 \\
=-5.8, P<0.001\end{array}$ \\
\hline & Repeated, at pregravid stage & $\begin{array}{l}35.7 \\
(32.0 ; 39.5)\end{array}$ & $\begin{array}{l}29.1 \\
(19.2 ; 34.5)\end{array}$ & & $\begin{array}{l}X_{1-2)}^{2}=40.926, P<0.001 \\
{ }_{1-2} U=940, Z=-5.5, P<0.001 \\
{ }^{2-3} U=4040, Z=-0.7, P=0.481 \\
=404, Z=-5.3, P<0.001\end{array}$ \\
\hline & Beginning of pregnancy & $\begin{array}{l}35.1 \\
(29.2 ; 38.7)\end{array}$ & $\begin{array}{l}19.4 \\
(14.9 ; 28.9)\end{array}$ & $\begin{array}{l}34.5 \\
(30.8 ; 38.6)\end{array}$ & $\begin{array}{l}X_{1-2)}^{2}=38.299, P<0.001 \\
{ }_{1-2} U=336, Z=-5.5, P<0.001 \\
{ }^{1-3} U=857, Z=-0.2, P=0.872 \\
2-3=219, Z=-5.2, P<0.001\end{array}$ \\
\hline & Before labour & $\begin{array}{l}30.8 \\
(24.5 ; 35.3)\end{array}$ & $\begin{array}{l}14.8 \\
(13.5 ; 24.4)\end{array}$ & $\begin{array}{l}30.5 \\
(18.1 ; 34.3)\end{array}$ & $\begin{array}{l}X_{1-2)}^{2}=37.391, P<0.001 \\
{ }_{1-2} U=254, Z=-5.8, P<0.001 \\
{ }^{2-3} U=233, Z=-1.0, P=0.335 \\
=2=-4.7, P<0.001\end{array}$ \\
\hline \multirow{3}{*}{ Osteocalcin, ng/ml } & Repeated, at pregravid stage & $\begin{array}{l}23.3 \\
(19.7 ; 25.5)\end{array}$ & $\begin{array}{l}17.0 \\
(13.6 ; 20.0)\end{array}$ & & $\begin{array}{l}X^{2}=53.332, P<0.001 \\
1-2 U=736, Z=-6.4, P<0.001 \\
1-3 U=1061, Z=-0.6, P=0.578 \\
{ }^{1-3} U=331, Z=-5.8, P<0.001\end{array}$ \\
\hline & Beginning of pregnancy & $\begin{array}{l}21.0 \\
(17.6 ; 23.3)\end{array}$ & $\begin{array}{l}13.8 \\
(9.3 ; 18.2)\end{array}$ & $\begin{array}{l}21.2 \\
(15.4 ; 23.8)\end{array}$ & $\begin{array}{l}X_{1(2)}^{2}=29.577, P<0.001 \\
{ }_{1-2} U=386, Z=-5.1, P<0.001 \\
{ }^{1-3} U=865, Z=-0.1, P=0.925 \\
{ }^{2-3} U=314, Z=-4.2, P<0.001\end{array}$ \\
\hline & Before labour & $\begin{array}{l}17.9 \\
(16.3 ; 21.6)\end{array}$ & $\begin{array}{l}12.3 \\
(8.8 ; 16.9)\end{array}$ & $\begin{array}{l}18.3 \\
(15.2 ; 20.3)\end{array}$ & $\begin{array}{l}X_{1-2)}^{2}=27.412, P<0.001 \\
{ }_{1-2}=348, Z=-5.0, P<0.001 \\
{ }^{1-3} U=809, Z=-0.6, P=0.553 \\
{ }^{2-3} U=291, Z=-4.0, P<0.001\end{array}$ \\
\hline \multirow[t]{4}{*}{ Vitamin D, ng/ml } & First, at pregravid stage & $\begin{array}{l}26.3 \\
(24.5 ; 30.2)\end{array}$ & $\begin{array}{l}28.0 \\
(25.0 ; 30.0)\end{array}$ & $\begin{array}{l}32.3 \\
(30.3 ; 35.0)\end{array}$ & $\begin{array}{l}X_{1-2)}^{2}=38.120, P<0.001 \\
1-2 U=1870, Z=-1.1, P=0.258 \\
1-3 U=384, Z=-5.4, P<0.001 \\
{ }^{2-3} U=357, Z=-5.6, P<0.001\end{array}$ \\
\hline & Repeated, at pregravid stage & $\begin{array}{l}33.8 \\
(29.7 ; 38.2)\end{array}$ & $\begin{array}{l}28.7 \\
(25.7 ; 31.4)\end{array}$ & & $\begin{array}{l}X_{1-2)}^{2}=36.414, P<0.001 \\
{ }_{1-2} U=969, Z=-5.3, P<0.001 \\
{ }^{1-3} U=1061, Z=-0.6, P=0.580 \\
{ }^{2-3} U=473, Z=-4.8, P<0.001\end{array}$ \\
\hline & Beginning of pregnancy & $\begin{array}{l}32.8 \\
(28.5 ; 36.3)\end{array}$ & $\begin{array}{l}27.1 \\
(24.1 ; 30.0)\end{array}$ & $\begin{array}{l}29.9 \\
(27.8 ; 33.3)\end{array}$ & $\begin{array}{l}X_{1-2)}^{2}=25.800, P<0.001 \\
{ }_{1-2}=394, Z=-5.0, P<0.001 \\
1-3 U=669, Z=-1.8, P=0.066 \\
2-3 U=439, Z=-2.9, P=0.004\end{array}$ \\
\hline & Before labour & $\begin{array}{l}29.3 \\
(26.1 ; 32.7)\end{array}$ & $\begin{array}{l}23.8 \\
(20.5 ; 27.8)\end{array}$ & $\begin{array}{l}28.0 \\
(25.8 ; 29.9)\end{array}$ & $\begin{array}{l}X_{(2)}^{2}=26.821, P<0.001 \\
{ }_{1-2} U=358, Z=-4.9, P<0.001 \\
{ }^{1-3} U=721, Z=-1.4, P=0.169 \\
{ }^{2-3} U=310, Z=-3.8, P<0.001\end{array}$ \\
\hline
\end{tabular}

*: The comparison of three groups (multiple comparisons Kruskal-Wallis test) further comparisons by pairs (test Mann-Whitney).

important to note that osteopenic syndrome was registered with every third woman with BWD (35.4\% (23 out of 65) group of suggested measures; $32.3 \%$ (21 out of 65 ) - group of traditional measures; in particular, osteoporosis was registered with two women (3.1\%) from the group of suggested measures and with 3 (4.6\%) from the group of traditional measures, whereas with women who had NBW no cases of osteopenic syndrome were registered.

After the received treatment with women who had BWD and who got suggested treatment and preventive measures, it was observed that mineral density of bone tissue grew better, as a result of it osteopenic syndrome of varying degree of severity was diagnosed with 13 women (20.0\%) from this group and with 19 patients (29.2\%) from group of traditional measures, but statistically considerable difference wasn't noted in comparison with women who received traditional treatment $\left(X_{(1)}^{2}=1.036, P=0.309\right)$ that coincides with opinion of researchers [7], who report that certain time is necessary for regeneration of mineral density of bone tissue.

Study of mineral density of bone tissue before labour effectively proved the advantage of suggested treatment. Comparison depending on the received treatment and preventive measures, revealed statistically considerable difference between groups (suggested measures $116.0 \%$ (8 out of 50 ), traditional $-51.4 \%$ (19 out of 37 ), $X_{(1)}^{2}=10.819$, $P=0.001)$, consequently the reduction of absolute risk that made up $68.0 \%$ (95\% Cl: 36.7-84.7\%) that can be compared to the clinically significant effect of proposed treatment. From the clinical point of view the amount of patients' rate who needed treatment in our research showed that for prevention of one case of osteopenic syndrome it is necessary to treat three patients with BWD $(2.895 \% \mathrm{Cl}$ : 1.8-6.1) with the help of suggested measures.

Thus, during the research made it was noted that women who had BWD already at pregravid stage had disorders of bone metabolism and coming of pregnancy when density 
of bone tissue is reduced can result in disturbance of bone metabolism.

That's why the solution of this problem was to add combined medicine of calcium with evident effect to traditional treatment and protective measures. As the results of investigation showed the use of combined medicine of calcium carbonate and cholecalciferol made indexes of calcium-phosphorus and bone metabolism better and also osteopenic syndrome less frequent.

\section{Conclusions}

1. The study of bone-mineral metabolism with women who have BWD at pregravid stage and pregnancy revealed statistically considerable reduction in blood of total calcium level and markers of bone tissue (PTH, osteocalcin, vita$\min \mathrm{D}$ ) that grew with the gestation course.

2. The existence of osteopenic syndrome at pregravid stage with every third woman who has BWD and before labour with every second showed the changes of mineral density of bone tissue.

3 . The use of elaborated medical preventive measures including combined medicine of calcium carbonate and cholecalciferol normalizes the indexes of bone-mineral metabolism with women who have BWD.

4. Taking of combined medicine of calcium with evident osteoprotective effect helps to minimize absolute risk of osteopenic syndrome (from 51.4 to $16.0 \%$ ) for $35.4 \%$ (95\% Cl: $16.3-54.4 \%)$, relative risk for $68.0 \%$ (95\% Cl: $36.7-84.7 \%$ ) that can be compared to clinically significant efficiency.

Prospects for future scientific research. Efficiency of elaborated medical preventive measures for women with BWD stresses expediency of researches showing its influence on frequency of obstetrician and perinatal complications for this category of patients.

\section{References}

[1] Dumanskaya, Yu., \& Shcherbavskaya, E. (2009) Issledovanie kostnoj tkani metodom dvukhe'nergeticheskoj rentgenovskoj absorbciometriej u devochek-podrostkov s narusheniem menstrual'nogo cikla [The Study of Bone Tissue by Method of Two-Energy X-Ray Absorptiometry in Teenager-Girls with Inpairment of Menstrual Functions]. Vestnik novykh medicinskikh tehnologij, 16(3), 56-58. [in Russian].

[2] Hollis, B. W., Johnson, D., Hulsey, T. C. Ebeling, M., \& Wagner, C. L. (2011) Vitamin D supplementation during pregnancy: doubl-blind, randomized clinical trial of safety and effectiveness. J Bone Miner Res, 26(10), 2341-57. doi: 10.1002/jbmr.463.

[3] Achkar, M., Dodds, L., Giguère, Y., Forest, J. C., Armson, B. A. Woolcott, C., et al. (2015) Vitamin D status in early pregnancy and risk of preeclampsia. Am J Obstet Gynecol, 212(4), 511. doi: 10.1016/j. ajog.2014.11.009

[4] Zhou, J., Su, L., Liu, M., Liu, Y., Cao, X., Wang, Z., \& Xiao, H. (2014) Associations between 25-hydroxyvitamin $D$ levels and pregnancy outcomes: a prospective observational study in southern China. Eur J Clin Nutr, 68(8), 925-30. doi: 10.1038/ejcn.2014.99.

[5] Price, C. T. Langford, J. R. \& Liporace, F. A. (2012) Essential nutrients for bone health and a review of their availability in the average North American diet. Open Orthopaedics J, 6, 143-9. doi: 10.2174/1874325 001206010143

[6] Kodencova, V. M., Vrzhesinskaya, O. A., Svetikova, A. A. \& Kaganov, B. S. (2009) Alimentarnye faktory riska razvitiya osteoporoza [Alimentary risk factors of osteoporosis]. Voprosy pitaniya, 178(1), 22-33. [in Russian].

[7] Shherbavskaya, E'. A., \& Gel'cer, B. I. (2003) Patofiziologicheskie aspekty osteopenii i osteoporoza pri beremennosti [Pathophysiological aspects of osteopenia and osteoporosis in pregnancy]. Rossijskie medicinskie vesti, 8(2), 28-33. [in Russian]

\section{Information about author:}

Shelestova L. P., MD, PhD, Associate Professor of Department of Obstetrics and Gynecology, Donetsk National Medical University, Lyman, Ukraine.

\section{Відомості про автора:}

Шелестова А. П., А-р меА. наук, доцент каф. акушерства та гінекології, Аонецький національний меАичний університет, м. Аиман, Україна.

\section{Сведения об авторе:}

Шелестова А. П., А-р меА. наук, Аоцент каф. акушерства и гинекологии, Аонецкий национальный медицинский университет, г. Аиман, Украина.

Конфлікт інтересів: відсутній.

Conflicts of Interest: author has no conflict of interest to declare.

Надійшло Ао редакції / Received: 20.04.2017

Після Аоопрацювання / Revised: 29.04.2017

Прийнято Ао Аруку / Accepted: 13.05.2017 